\title{
PROTECTION OF INTELLECTUAL PROPERTY RIGHTS UNDER THE EUROPEAN CONVENTION ON HUMAN RIGHTS AND FUNDAMENTAL FREEDOMS
}

\section{ЗАХИСТ ПРАВ ІНТЕЛЕКТУАЛЬНОЇ ВЛАСНОСТІ ВІДПОВІДНО ДО ЄВРОПЕЙСЬКОЇ КОНВЕНЦЇ̈ 3 ПРАВ ЛЮДИНИ І ОСНОВОПОЛОЖНИХ СВОБОД}

\author{
Mezentseva O.O., Student of the Faculty of Economics and Law \\ Yaroslav Mudryi National Law University
}

This article is dedicated to the study of protection of intellectual property rights under the European Convention on Human Rights and Fundamental Freedoms. An analysis of the decisions of the European Court of Human Rights on the protection of violated rights established in Article 1 of Protocol 1 to the European Convention for the Protection of Human Rights and Fundamental Freedoms, namely the right to peacefully own property and the application of such a right to intellectual property. Consideration of cases applicable to the coverage, protection and development of the rules established by the Convention on Human Rights and Fundamental Freedoms, which facilitates States' compliance with the obligations they have assumed as Contracting Parties. The main task of the system set up by the European Convention on Human Rights and Fundamental Freedoms is to identify issues of public policy in the general interest, raising human rights standards and extending human rights jurisprudence throughout the society of the Member States. The number of The European Court of Human Rights cases on intellectual property matters is not large, but may increase in the last few years. The development of information technology leads to a qualitative and quantitative expansion of the sphere of protection of copyright and related rights. The European Court of Human Rights accepts and promotes the protection of new forms of intellectual property. The article also explores the protection of property rights with other fundamental rights enshrined in the European Convention on Human Rights and Fundamental Freedoms, namely the right to freedom of expression. The case law of the European Court of Human Rights, which shows that freedom of expression, is enshrined in Article 10 of the Convention for the Protection of Human Rights and Fundamental Freedoms, may in certain circumstances prevail intellectual property rights. Concerning, in particular, cases in which questions arise concerning rights other than the right under Article 1 of Protocol 1 to the European Convention for the Protection of Human Rights and Fundamental Freedoms, it is noteworthy that the approach of the Court is no different from its usual approach, it considers and reconciles various rights and assesses the need and proportionality of interference with the exercise of a particular right.

Key words: intellectual property, property rights, European Convention on Human Rights and Fundamental Freedoms, Protocol No. 1 to the European Convention for the Protection of Human Rights and Fundamental Freedoms, case-law, the European Court of Human Rights.

Стаття присвячена дослідженню захисту прав інтелектуальної власності відповідно до Європейської конвенції з прав людини і основоположних свобод. Аналізуються рішення Європейського суду з прав людини щодо захисту порушених прав, установлених статтею 1 Протоколу 1 до Європейської конвенції про захист прав людини і основоположних свобод, а саме права мирно володіти майном і застосування такого права на інтелектуальну власність. Розглядаються справи, що застосовуються до висвітлення, захисту та розвитку правил, установлених Європейською конвенцію з прав людини і основоположних свобод, що сприяє виконанню державами зобов'язань, які вони взяли на себе як Договірні Сторони. Завдання системи, створеної Європейською конвенцією з прав людини і основоположних свобод, полягає у визначенні питань державної політики в загальних інтересах, що підвищує стандарти захисту прав людини та розширює судову практику у сфері прав людини в усьому товаристві держав-членів. Практика Європейського суду з прав людини щодо питань інтелектуальної власності не велика, але збільшується протягом останніх років. Розвиток інформаційних технологій призводить до якісного та кількісного розширення сфери захисту авторських і суміжних прав. Європейський суд з прав людини приймає нові форми та сприяє захисту нових форм інтелектуальної власності. У статті також досліджується захист прав інтелектуальної власності з іншими основними правами, закріпленими Європейською конвенцією з прав людини і основоположних свобод, а саме право на свободу вираження поглядів. Практика Європейського суду з прав людини свідчить про те, що свобода вираження поглядів закріплена в статті 10 Конвенції про захист прав людини і основних свобод, може за певних обставин переважати право інтелектуальної власності. Стосовно випадків, коли виникають питання, що стосуються інших прав, ніж права, передбаченого статтею 1 Протоколу 1 до Європейської конвенції про захист прав людини і основоположних свобод, варто зазначити, що підхід Європейського суду з прав людини не відрізняється від його звичайного підходу, він ураховує та узгоджує різні права й оцінює необхідність і пропорційність втручання в здійснення конкретного права.

Ключові слова: інтелектуальна власність, право власності, Європейська конвенція з прав людини і основоположних свобод, Протокол 1 до Європейської конвенції про захист прав людини і основоположних свобод, прецедентне право, Європейський суд з прав людини.

Owners of property rights often suffer from misuse. There are no exemptions among intellectual property owners (hereinafter referred to as IP). The reasons for such a negative phenomenon are the insufficient awareness of the authors themselves about ways of protecting their works, the gaps in the national legislation and the lack of an effective institution for protection against growing such infringements and so on The popularity of this topic is also due to the active development of the Ukrainian market, which creates competitive products and a wide range of services and enters the international level. The international cooperation of States in the field of human rights takes the form of the introduction of certain standards regarding the content of the legal status of an individual and the acceptance by States of obligations to comply with these standards in their domestic legislation and in their daily activities. Proper and effective protection of human rights is exercised in accordance with the European Convention on Human Rights (hereinafter referred to as the Convention). Ratified the Convention Ukraine has recognized its activities in its territory and the jurisdiction of the European Court of Human Rights (hereinafter referred to as ECtHR) in all matters relating to the interpretation and application of the Convention.

Due to the growing demand for IP rights, there is increasing interest from scholars to study and analyze this issue. Among the authors who have dedicated their work to this aspect: Peter K. Yu, David S. Welkowitz, Harry Goldsmith, David Weissbrodt, Kell Schoff, Allard Ringnalda, Ruth L. Okediji, Jacob Cornides, Laurence R. Helfer and many others. The study of this issue among provided by national scientists such as T. Slinko, N. Blazhivska, A. Chervyatsova, O. Posikalyuk and others.

The purpose of the article is to explore the possibility of applying intellectual property rights protection to the ECtHR and to review other articles that are more closely related to the protection of intellectual property rights, as well as to analyze the ECtHR's decision to violate the right provided for in Article 1 of Protocol No. 1. No. 1 to the ECtHR of March 20, 1952 (hereinafter referred to as Protocol No. 1).

The intellectual property system provides protection based on the requirements of the intellectual property industries and their powerful and supportive governments. 
As a result, the level of protection afforded by intellectual property legislation is higher and often much higher than the levels required by international or regional human rights instruments [1]. The number of ECtHR cases on intellectual property is not large, but there is an increase in the last few years. The ECtHR's decisions are used not only to resolve the cases at hand, but also to provide general coverage, protection and development of the rules established by the Convention, which facilitates States' fulfillment of their obligations as Contracting Parties [2]. Protocol No. 1 defines property protection, the right to education and the right to free elections [3]. It came into force in 1954 and was signed by all Member States. With the exception of Switzerland and Monaco, all countries have also ratified Protocol No. 1. Article 1 of Protocol No. 1 guarantees ownership. In Marckx v. Belgium [4], §§ 63-64, the ECtHR initially stated that: “... Recognizing that everyone has the right to the peaceful enjoyment of his possessions, Article 1, in effect, guarantees ownership. The words "property" and "use of property" (in French: "biens", "propriété", "use des biens") have left this clear impression; The travaux préparatoires, for their part, unequivocally confirm this: developers continued to say "ownership" or "ownership" to describe the subject of subsequent projects that were the precursors to this article 1 . Indeed, the right to dispose of property is a traditional and fundamental aspect of property rights ... However, the second paragraph of Article 1 enables the Contracting State to "apply such laws as it deems necessary to control the use of the property in the general interest or to secure the payment of taxes or other contributions $h$ and penny "Therefore, this paragraph designates Contracting States to determine for themselves the" necessity "of such a law ... As for" common interests", this provision may in some cases induce the legislature to exercise" control over the use of property" (...)

According to the decision of Anheuser-Busch Inc. v. Portugal, Article 1 of Protocol No. 1 applies to IP: "In view of the above decisions, the Grand Chamber agrees with the Chamber that Article 1 of Protocol No. 1 applies to intellectual property as such ..." [5]. In this particular case, the applicant, a well-known brewing company, claimed that he had been deprived of his "property" within the meaning of Article 1 of Protocol No. 1 to the Convention on the Protection of Property Rights by refusing to register a trade mark for the well-known Budweiser beer produced and sold by the company; the refusal of registration was conditioned by the application of a bilateral international treaty, which came into force after the application for registration of the trademark The Grand Chamber found that the Portuguese authorities, including the courts, had rightly refused registration of the beer trademark and did not find any violation of Article 1 of Protocol No. 1 to the Convention.

Considering property rights, namely ownership of the physical owner of the relevant right, the ECtHR has recognized that Article 1 of Protocol No. 1 to the ECtHR applies to the exclusive right to use and dispose of registered domain names on the Internet. This is "property" in the case of Paeffgen GmbH v. Germany [6]. In this case, the ECtHR considered the issue of domain name registration and possible interference with the exercise of third party rights. The court's decision prohibiting the use and requesting the removal of domain names registered in the applicant's name but interfering with the rights of third parties served to achieve a legitimate common interest in maintaining a functioning trademark system and/or names. National authorities had wide restrictions on discretion. However, their decisions struck a fair balance between the protection that the owner of the exclusive right to use the domain name should receive and the requirements of the common interest "ownership" should not have been borne by the individual or the overburden.

Article 1 of Protocol No. 1 applies to a license to provide Internet access. Review of ECtHR Megadat.com SRL v. Moldova [7] argued that such a license is "proprietary".
Inthepresentcase, concerning the company which was the largest Internet service provider in Moldova, the applicant company complained of invalidation of its telecommunications licenses on the ground that it did not notify the competent supervisory authority of the change of address. She further stated that she was the only one of the 91 companies to be severely punished. As a result, the company had to cease operations. The court noted that the trial in the courts of Moldova appeared to be very formal. No attempt was made to establish a link between the general problem of the case and the sanction applied to the applicant company. Accordingly, the Court considers that the proceedings were arbitrary and that an excessively severe measure had been taken against the company. In addition, in view of the discriminatory treatment of the company, the Court concludes that its consistent policy considerations were invalidated by its own authorities in invalidating Megadat. com SRL licenses. Therefore, there was a violation of Article 1 of Protocol No. 1

With regard to property rights, it should be noted that case law only partially covers this component of intellectual property rights. Thus, the ECtHR found that the right to publish a translation of a novel falls within the scope of Article 1 of Protocol No. 1. Moreover, the deprivation of such property can only be justified by reference to the public interest, with due regard for the law and the proportionality of the objective pursued. In the case of SC Editura Orizonturi SRL v. Romania [8] The ECtHR found that, although the state has broad discretion, it cannot justify the deprivation of property lawfully acquired (infringement). It is noticeable from the case of AD v. The Netherlands [9], the fact that public authorities intercepted correspondence addressed to a third party in the defamatory behavior did not reveal any appearance of interference with the applicant's intellectual property rights under Article 1 of Protocol No. 1. Therefore, the complaint was clearly unreasonable.

The foregoing analysis shows that the ECtHR's approach to resolving conflicts in the context of free movement and fundamental rights is various ways, which is not always a proper justification. It is argued that the Court should learn more from the case law on free movement also to resolve IP conflicts with other fundamental rights [10]. Issues arising from the use of their "property" may also apply to other articles of the Convention. Thus, Article 10 of the Convention [11], which provides for the right to freedom of expression, is closely linked to the protection of intellectual property rights. In the Handiside v. The United Kingdom case [12], the applicant complained about the removal of duplicates of the Red Book of the Schoolboy (school textbook), as well as their confiscation and subsequent destruction after a national court. The ECtHR found that the purpose of the arrest was to "protect morality", as evidenced by the position of the competent British authorities in the exercise of their powers. The confiscation and destruction of such material permanently deprived the applicant of property rights. However, these measures have been authorized in accordance with Article 1, paragraph 2, of Protocol No. 1, with a view to identifying certain possibilities, taking into account the principle of law common to the Contracting States, where, under articles recognized by the law as illegal and of general interest, interest has been lost for the purpose of destruction. Therefore, there was no violation of Article 1 of Protocol No. 1 or Article 10 of the Convention.

In the case of Ozurk v. Turkey [13], the ECtHR acknowledged that the removal and destruction of copies of a book published by the applicant publisher was only a legal aspect of his belief in the propaganda of separatist propaganda (considered in accordance with Article 10). It was therefore superfluous to consider this confiscation separately under Article 1 of Protocol No. 1. In Ashby Donald and Others v. France [14], the ECtHR acknowledged that, when it comes to interference with the right to freedom of expression, States 
enjoy broader discretion when challenged the measure seeks to protect other rights enshrined in the Convention, such as the right to peaceful enjoyment of property, including in this case copyright protection.

To sum up, the intellectual property system grants protection based on demands from intellectual property industries and their powerful and supportive governments. Whenever two values conflict, the primary task of the Court is to try to reconcile them by finding a middle ground. Furthermore, ECtHR accepts and promotes the protection of new forms of intellectual property (Internet access license, domain name, etc.). The number of ECtHR cases on IP matters is not large, but increase in the last few years. From this review of case law in the field of intellectual property, it is noticeable that, despite the importance of using the Internet today, the number of disputes concerning it is small. As for, in particular, cases in which questions arise concerning rights other than the right under Article 1 of Protocol No. 1, it is noteworthy that the approach of the Court is no different from its usual approach, it considers and reconciles various rights and assesses the need and proportionality of interference with the exercise of a particular right.

\section{REFERENCES}

1. Peter K Yu, "Intellectual Property and Human Rights 2.0." University of Richmond Law Review, vol. 53, no. 4, May 2019, p. $1375-1454$.

2. Ireland v. the United Kingdom, 18.01.1978, Series A no. 25. URL: http://hudoc.echr.coe.int/eng?i=001-57506.

3. Protocol 1 to the European Convention for the Protection of Human Rights and Fundamental Freedoms, 20.03.1952. URL: https://www.coe.int/en/web/echr-toolkit/protocole-1.

4. Marckx v. Belgium: Court (Plenary) Judgment (Merits and Just Satisfaction). 13/06/1979. App. No. 6833/74. URL: http://hudoc.echr.coe. int/eng?i=001-57534.

5. Anheuser-Busch Inc. v. Portugal: Court (Grand Chamber) Judgment (Merits and Just Satisfaction). 11/01/2007. App. 73049/0. URL: http://hudoc.echr.coe.int/eng?i=001-78981.

6. Paeffgen Gmbh v. Germany App. Nos. 25379/04, 21688/05, 21722/05 and 21770/05, Decision, 18.09.2007. URL: https://protocol.ua/ua/paeffgen_gmbh_proti_nimechchini_pravo_na_domenne_im_ya_e_pravom_vlasnosti_(st_1_prrtokolu_1 konventsii zaya vi_25379_04_21688_05_21722_05_ta_21770_05_vid_18_veresnya_2007_roku)/.

7. Megadat.com SRL v. Moldova: Court (Third Section) Judgment (Just Satisfaction). 17/05/2011. App. 21151/04. URL: http://hudoc.echr. coe.int/eng?i=001-144491.

8. SC Editura Orizonturi SRL v. Romania: Court (Third Section) Judgment (Merits and Just Satisfaction). 13/05/2008. App. 13/05/2008 URL: http://hudoc.echr.coe.int/eng?i=001-122507.

9. A.D. v. the Netherlands App. 21962/93, Decision, 11/01/1994. URL:https://www.google.com.ua/url?sa=t\&rct=j\&q=\&esrc=s\&sourc e=web\&cd=1\&cad=rja\&uact=8\&ved=2ahUKEwiw3f73y67oAhVx-SoKHcDRAtIQFjAAegQIAxAB\&url=https\%3A\%2F\%2Fwww.echr.coe. int\%2FDocuments\%2FResearch_report_Internet_RUS.pdf\&usg=AOvVaw17J5RoBk2OGcNDyLCmfCEL.

10. Martin Husovec, "Intellectual Property Rights and Integration by Conflict: The Past, Present and Future". Cambridge Yearbook of European Legal Studies, 18, 2016, p. 239-269.

11. Konventsiia pro zakhyst prav liudyny i osnovopolozhnykh svobod vid 04.11.1950 roku. URL: http://zakon.rada.gov.ua/laws/card/ $\mathrm{ru} / 995$

12. Handyside v. the United Kingdom: Court (Plenary) Judgment (Merits). 07/12/1976. App. 5493/72. URL: http://hudoc.echr.coe.int/ eng?i=001-165143.

13. Ozturk v. Turkey: Court (Grand Chamber) Judgment (Merits and Just Satisfaction). 28/09/1999. App. 22479/93. URL: http://hudoc.echr. coe.int/eng?i=001-58305.

14. Ashby Donald and Others v. France: Legal Summary, 10/01/2013, 36769/08 URL: http://hudoc.echr.coe.int/eng?i=002-7393. 